\title{
MODEL OF ESTIMATION OF SUCCESS OF GEOLOGICAL EXPLORATION IN PERSPECTIVE
}

\section{T. MUHAMEDIYEVA}

Center of Development Hardware and Software Products at Tashkent University of Information Technologies,

Tashkent, Uzbekistan

In this article discusses the development of a system of interrelated mathematical models, algorithms and programs of the decision task according to the assessment, forecasting and risk management to reduce their value in a multistage process; development of instrumentation and software means of the computational experiment for the simulation and research of risk models and algorithms of decision making for their management.
\end{abstract}

KEYWORDS: Geological Exploration, Fuzzy Sets Theory, Membership Function \& Strategy

Received: Jan 15, 2018; Accepted: Feb 05, 2018; Published: Mar 08, 2018; Paper Id: IJMPERDAPR201861

\section{INTRODUCTION}

Oil and gas industry, as a complex production system, is characterized by several specific features that distinguish it from other branches of material production. Most significant of them from the point of view of the analysis and risk assessment are the large dependence of the indicators and criteria of efficiency of functioning of the production system: natural conditions; level of use of proven and recoverable hydrocarbon resources; dynamic nature (variability in time) by natural factors; probabilistic nature of most technical and economic indicators of oil and gas development and production processes; changes in the reproduction structure of capital investments in the industry in the direction of increasing their share allocated to compensate for the production decline in old fields; extended duration of implementation of the oil and gas projects; high capital intensity of oil and gas production; the need for large investments; long period of recovery of initial capital etc. Geological and geophysical surveying, exploration and industrial exploration, exploration drilling, the definition of stocks - all these stages of a multistage process (Geophysics - Geology - search intelligence-industrial intelligence - a definition of reserves) are applied to the same object, investigated the productive formation of oil and gas.

When conducting research on each of these stages need to evaluate the information in the form of aggregate information features indirectly connected with the main object of study, the decision on which is largely based on the experience and intuition of the researcher, is able to carry out a comparative analysis using a successful analogy, but also with the objective of the geophysical, geological and other laws have long been successfully used in the research process.

Peculiarities of the considered multistage processes the oil and gas industry, describing them as complex, dynamic, and substructure objects that influence the appearance of different types of risk. Specific to the oil and gas industry are the following risks: risk of undiscovered deposits; risk associated with inaccurate determination of geological characteristics of the development (the amount of geological reserves), and probabilistic and often 
uncertain (stochastic) nature of the production process (the dynamics of production and processing of hydrocarbons, etc.) risk associated with the completion of the project; risk associated with the conditions of the market of oil, gas and petroleum products; risk caused by the increased likelihood of the occurrence of force majeure. Main reasons for risks arising in the implementation of oil and gas projects are the distribution of production-economic returns from the project over time; the dispersion of values of each variable affecting the amount of the performance criteria; the significant costs associated with collecting additional information. All project participants are interested in how to reduce the risk of making bad (inefficient) decisions to avoid a complete failure of the project or at least significant losses. For this project, participants have to consider all the possible consequences of the project implementation in a rapidly changing market environment.

The main purpose of the risk analysis and management to reduce its value is to give potential partners the necessary information for making decisions about the assessment of the degree of acceptability of project decisions about whether to participate in the project and provide measures to protect against possible financial losses or minimize them.

The distinctive feature of the nature of these risks is that they have both a probabilistic (stochastic), and, increasingly, non-stochastic (uncertain) nature when the probabilistic characteristics of the processes or problematic receive them. Therefore, to study these processes a new rapidly developing "soft system methodology". The basic apparatus of this methodology are the methods of fuzzy set theory, neural networks, and genetic algorithms, which constitute the modern technology of Computational Intelligence. The task of risk management of multi-stage processes requires systematic analysis, classification and formal description, and design of interconnected mathematical models, algorithms and programs for solving problems of decision making in assessing, forecasting and risk management, to reduce their value to an almost acceptable in each of the studied stages. An important task is also the establishment of appropriate instrumental-programmatic and institutional computing experiment, which will allow for simulation modeling, including real data collected by a system of interconnected models, as well as the study of the developmental algorithms and programs for decision making on risk management.

Received and validated models, algorithms and risk management program can be the basis for a model of shells on intelligent systems for decision support (DSS) for risk management in multi-step processes in conditions of uncertainty.

\section{PROBLEM STATEMENT}

Development and implementation of exploration projects always take place in conditions of some uncertainty, due to:

Incomplete knowledge of all parameters of the circumstances of the situation necessary to select optimal solutions, the impossibility of adequate and precise record of all, even available information, as well as the probability characteristics of the behavior of your environment;

Factors that cannot be foreseen, and predicted even in a probabilistic implementation, i.e. factors of randomness;

Subjective opposing factors when decisions are made in a situation of the game, partners with the opposite or something, but coinciding interests.

Thus, the implementation of the exploration project is carried out in conditions of uncertainty and risks. 
Currently, the main problems faced by experts when conducting geological exploration, due to the fact that the parameters of promising structures in the fields included in calculation formulas, usually unknown or known with the very large error. Therefore, it is often necessary to make decisions in conditions of the uncertainty of various types.

To study processes and assessment of the probability of success to the discovery of promising structures should meet the following objectives:

- Ranking of objects (sedimentary basins and their parts) for further research on models of decision-making.

- The selection of priority areas for the work of the next stage.

- Evaluation of the effectiveness of each stage.

- $\quad$ Suggestions for further work.

In the model the possibility (expected) occurrence of events corresponding orientation, which is seen as an opportunity or a risk for this stage. Often the leaders are inclined to believe that to determine the probability of occurrence of events quantitatively. Of course, for a quantitative assessment, there is no reason. The term "probability" in this use is not tenable, because single heterogeneous origin events does not have the statistics, and to talk about the frequency of their occurrence is impossible. Immediately suggests two ways of introducing fuzzy descriptions:

- Replacement of the "probability" with the expectation expressed in qualitative terms "very low expectations," "low expectations," "average expectations," "high expectations," "very high expectations." At the same time, the quantitative carrier cannot be compared with the expectation itself;

- Replacing the binary scale "opportunity / risk for geological exploration" with a 5-state scale: "rather, possibility", "supposedly possibility", "uncertainty", "presumably risk", "rather, risk."

Formation of the field events (and their evaluation) may be made on the basis of the expert survey.

To assess the strengths and weaknesses of exploration it is possible to use both quantitative and qualitative scale.

We introduce a two-tier scale that contains a number of basic factors, which in turn are characterized by the sets of their constituent factors. As underlying factors that characterize the strength/weakness of exploration, you can choose from the following: technology, Quality, Costs, Sales, Prices, Service, and logistics.

Let's introduce the linguistic variable "Level of the factor" a subset of "Very low", "Low", "Average", "High" "Very high level" and enter the carrier of the $\mathrm{x}$ - segment of the real axis [0,1] (01 carrier), which define a set of membership functions for all the selected subsets of the linguistic variable "Level factor". It is advisable that such membership functions had Acme. The upper base of the trapezoid corresponds to $100 \%$ confidence of an expert in the supplies of factor levels selected fuzzy subset (projection of the upper base of the trapezoid in the area of the media definition forms a confidence interval). As the distance from the confidence interval, the confidence of the expert in classification is reduced to zero, which expresses the lateral edges of the trapezoid. The projection of these edges on the scope of a carrier gives two intervals of uncertainty. All other intervals to determine media form a combined interval of uncertainty (expert $100 \%$ sure that these levels do not belong to the fuzzy subset). An example of such a fuzzy classification derived in [1], shown in Figure 1 (we call such a classification standard fuzzy five-level 01-classification). 


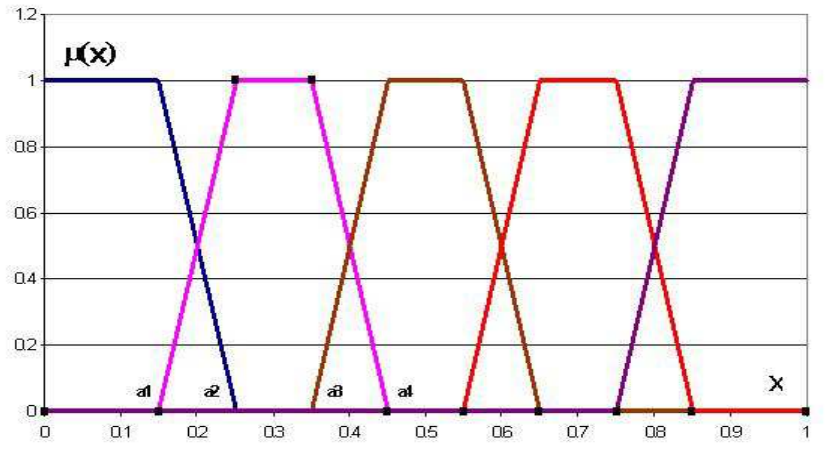

Figure 1: Membership Functions of Linguistic Variable "Level of Factor"

If you define for each component factor of the level quantitatively ( 0 to 1$)$, the level of the underlying factor may be determined both quantitatively and qualitatively according to the matrix principle, which essentially consists in the following [1]. Let the rows of the matrix components of the deferred factors, and the columns - they are the levels expressed by an appropriate set of membership functions. Then the integral indicator of the strength/weakness of exploration work on the base I-the factor is defined as the double convolution:

$$
\mathrm{SW}_{\mathrm{i}}=\sum_{(\mathrm{j})} \mathrm{p}_{\mathrm{ij}} \sum_{\mathrm{k}=1}^{5} \alpha_{\mathrm{k}} \mu_{\mathrm{ijk}}\left(x_{j}\right),
$$

where $x_{j}$ - quantitative value of the $j$-the component of the vector, $p_{i j}$ - weight of the $j$-the component of the factor in assessing the strength/weakness of exploration work on the base of the I-the factor, $\mathrm{M}_{\mathrm{ijk}}-$ value of the k-the membership function in determining the level of the $\mathrm{j}$-the component of the vector (a total of five functions, the number of subsets), $a_{k}=$ $0.1 * \mathrm{k}$ - set of weights of States in the integral convolution (the so-called nodal points, uniformly deposited on the 01carrier).

And it is fulfilled:

$$
\sum_{\mathrm{k}=1}^{5} \mu_{\mathrm{ijk}}(x)=1
$$

For any values of the carrier of $\mathrm{x}$, and the weighting system of the indicators should sum to give the unit:

$$
\sum_{(j)} \mathrm{p}_{\mathrm{ij}}=1
$$

In virtue of (1) to (3) the condition $0 \leq \mathrm{SW}_{\mathrm{i}} \leq 1$, and therefore, the obtained value can be recognized according to the General rules defined for 01 vehicles.

The above matrix principle will be referred to hereafter as the standard principle of matrix estimation of the factor level.

\section{MATRIX ASSESSMENT OF THE LEVEL OF FACTOR}

If experts evaluated the attractiveness of objects to enter into deep exploration drilling at desyatiballnoy scale, then the histogram of the form of Figure 2 of the carrier of $X=[0,10]$, we define the average value $\mu$ histograms and 
standard deviation (SD) $\sigma$. Build a set of five nodal points epatirovala classifier rule:

$$
\begin{aligned}
& \mu_{1}=\mu-\mathrm{t}_{1} \sigma, \\
& \mu_{2}=\mu-\mathrm{t}_{2} \sigma, \\
& \mu_{3}=\mu, \\
& \mu_{4}=\mu+\mathrm{t}_{2} \sigma, \\
& \mu_{5}=\mu+\mathrm{t}_{1} \sigma,
\end{aligned}
$$

where $t_{i}$ - coefficients in classical statistics are the ratios of Student. For each nodal point of the classifier is true that it is the level of the factor is recognized, uniquely, an expert with absolute confidence. For example, point $\mu_{1}$ corresponds to a very low level of the factor (HE), $\mu_{2}-$ as $\mathrm{N}$ etc.

Next divide each segment $\left[\mu_{\mathrm{i}}, \mu_{\mathrm{i}+1}\right]$ into three zones: the zone of absolute certainty, the zone of low certainty and absolute uncertainty. The lengths of these three zones form the proportion $1: \mu: 1$, where the parameter $\mu \geq 0$ expresses the depth of uncertainty. Thus, when $\mathrm{u}=0$ low there is no certainty, and the delimitation of the zones is hard (interval).

Applied additional points (boundaries of zones of confidence-uncertainty) on the axle carrier of the factor. Then it is possible in the zone of confidence to adopt a membership function 1 , in the area of absolute uncertainty at 0 , and the area of uncertainty to describe the sloping edge of the corresponding trapezoidal fuzzy number. Thus, the first approximation of petascale built.

In our case, when $\mathrm{X}=[0,10], \mu=4.5, \mathrm{RMS}=2$. Also set $\mathrm{u}=1$, i.e. all the zones of certainty - low certainty uncertainty are of equal length.

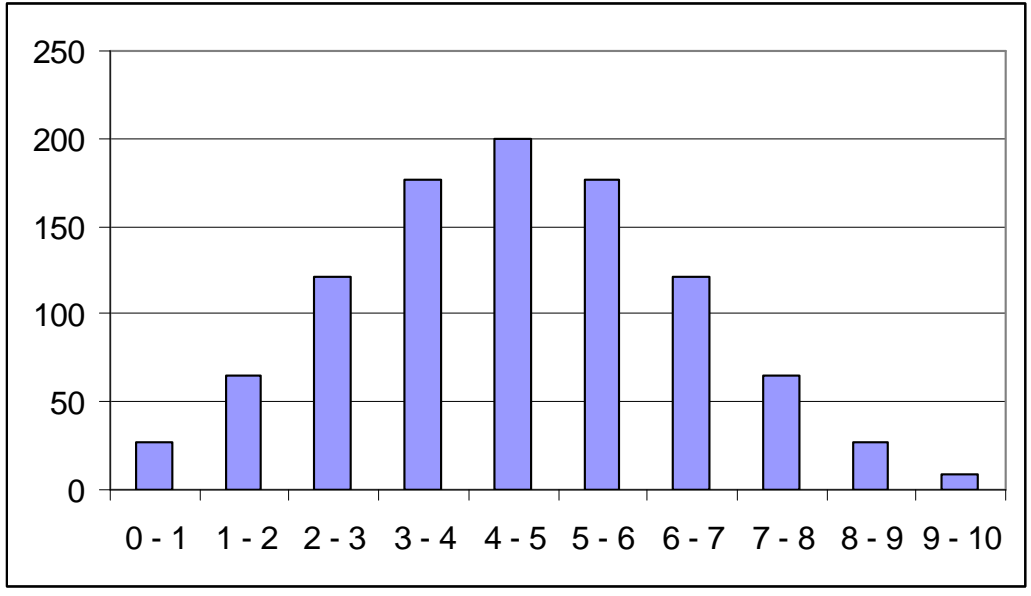

Figure.2: Histogram of Normally Distributed Statistics.

Thus, the intervals of zones of absolute certainty the following:

VL: $\quad[0,0.5+(2-0.5) / 3]=[0,1]$

L: $\quad[2-(2-0.5) / 3,2+(4.5-2) / 3]=[1.5,2.83]$;

$\mathrm{A}: \quad[4.5-(4.5-2) / 3,4.5+(7-4.5) / 3]=[3.67,5.33]$; 
$\mathrm{H}: \quad[7-(7-4.5) / 3,7+(8.5-7) / 3]=[6.17,7.5]$

VH: $\quad[8.5-(8.5-7) / 3,10]=[8,10]$

We will use the set of membership functions in the form of Figure 1. Then as the family of membership functions can be a standard five-level 01-classifier [4], where the membership function trapezoidal triangular numbers (Figure 1)

$V L: \mu_{1}(x)=\left\{\begin{array}{c}1,0 \leq x<0.15 \\ 10(0.25-x), 0.15 \leq x<0.25 \\ 0,0.25 \leq x \leq 1\end{array}\right.$

$\mathrm{L}: \mu_{2}(\mathrm{x})=\left\{\begin{array}{c}0,0 \leq \mathrm{x}<0.15 \\ 10(\mathrm{x}-0.25), 0.15 \leq \mathrm{x}<0.25 \\ 1,0.25 \leq \mathrm{x}<0.35 \\ 10(0.45-\mathrm{x}), 0.35 \leq \mathrm{x}<0.45 \\ 0,0.45 \leq \mathrm{x}<=1\end{array}\right.$

$A: \mu_{3}(x)=\left\{\begin{array}{c}0,0 \leq x<0.35 \\ 10(x-0.35), 0.35 \leq x<0.45 \\ 1,0.45 \leq x<0.55 \\ 10(0.65-x), 0.55 \leq x<0.65 \\ 0,0.65 \leq x<=1\end{array}\right.$

$H: \mu_{4}(x)=\left\{\begin{array}{c}0,0 \leq x<0.55 \\ 10(x-0.55), 0.55 \leq x<0.65 \\ 1,0.65 \leq x<0.75 \\ 10(0.85-x), 0.75 \leq x<0.85 \\ 0,0.85 \leq x<=1\end{array}\right.$

VH: $\mu_{5}(x)=\left\{\begin{array}{c}0,0 \leq x<0.75 \\ 10(x-0.75), 0.75 \leq x<0.85 \\ 1,0.85 \leq x \leq 1\end{array}\right.$

Standard classifier performs the projection of the fuzzy linguistic description on 01-carrier, while doing it in a consistent way, symmetrical positioning the node classification $(0.1,0.3,0.5,0.7,0.9)$. At these sites, the value of the corresponding membership function is equal to unity, and all the other functions - zero. The uncertainty of expert classification decreases (increases) linearly with distance from the node (the end node, respectively); the sum of the membership functions of all points media is one.

Accordingly, the detection level gives that the first contributing factor in the degree of 0.5 confidence is high and with the same confidence is very high. The detection level of the second constituting factor gives an unequivocal recognition of the level of average. 
To assess the strength/weakness of the business the underlying factor that will make the table to calculate the SW by the formula (1).

Thus, it is possible to implement a matrix convolution in the transition from individual indicators of the strength/weakness of exploration work on the underlying factors to the overall indicator of strength/weakness exploration. Only need to determine the weights of the underlying factors in the integral evaluation.

Let us have two integral meters for geological prospecting: the attractiveness of objects for entering into deep search drilling and its favorability for the formation and preservation of deposits. Then we can conduct the analysis.

Attraction (A) can be measured based on the following basic factors:

- Availability of oil and gas reservoirs $-\mathrm{a}_{1}$;

- Availability of favorable temperature and pressure conditions to convert the hydrocarbons in the $\mathrm{S}-\mathrm{a}_{2}$;

- The chances of achieving the flow of hydrocarbon traps $-\mathrm{a}_{3}$;

- Friendliness of the object (B) can be measured based on the following basic factors:

- $\quad$ By traps square $-b_{1}$;

- $\quad$ By traps square $-\mathrm{b}_{2}$;

- $\quad$ By the depth of occurrence of productive horizons $-b_{3}$;

- $\quad$ On the availability and quality of tires $-b_{4}$;

- $\quad$ By the number of expected deposits $-b_{5}$;

- In terms of prospective resources $-b_{6}$;

- $\quad$ remoteness from the deposit $-b_{7}$;

- $\quad$ Remoteness from drilled "empty areas"- $b_{8}$.

All these basic factors $a_{i}, b_{j}$ you can map the 01-carrier. If historically, these factors are measured on the basis of other quantitative scales (e.g., from 1 to 5), it is possible to make the transition from the existing scale to the 01-carrier on the basis of simple linear transformation.

A quantitative estimate of the integral factors A and B can be carried out according to the formula (1) (standard matrix scheme of evaluation), but to recognize the level of these factors should be applied not the standard five-level 01classification (Figure 1), and a three-level 01-classification (Figure 3), with the subsets "Low level, Medium level, High level" linguistic variable "Level factor".

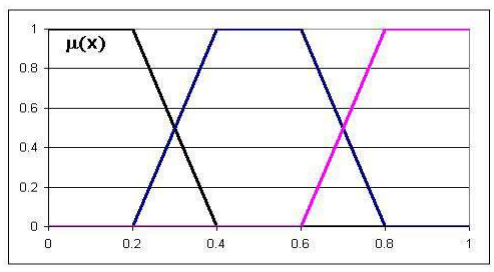

Figure 3: Three-Level 01-Classification 
Weight basic factors in the integral evaluation are selected on the basis of additional considerations. One of these reasons may be the principle Fishburne. If you know the system preferences of some other factors in the system of $\mathrm{N}$ factors, the weight factors are arranged in descending order and evaluated by the formula [1,2]:

$$
\mathrm{p}_{\mathrm{i}}=\frac{2(\mathrm{~N}-\mathrm{i}+1)}{\mathrm{N}(\mathrm{N}+1)}
$$

If the factors have equal preference for assessment, they must log in to a convolution with equal weights.

Let the integral factor A of geological exploration for the first object be determined by three basic factors with a system of weights and the quantitative levels established by Table 1, and the integral factor B of the same exploration is determined by eight basic factors with a system of weights and quantitative levels established by Table 2 . It is required to qualitatively determine the levels of integral factors A and B based on the three-level 01-classification.

Table 1: Matrix for Evaluation of the Integral Factor A

\begin{tabular}{|c|c|c|c|c|c|c|}
\hline \multirow[b]{2}{*}{ Factors } & \multirow[b]{2}{*}{ Weights } & \multicolumn{5}{|c|}{ Membership Functions for Levels of the Constituent Factors: } \\
\hline & & Very Low $\left(\mu_{1}\right)$ & $\begin{array}{l}\text { Low } \\
\left(\mu_{2}\right)\end{array}$ & $\begin{array}{c}\text { Average } \\
\left(\mu_{3}\right)\end{array}$ & $\begin{array}{c}\text { High } \\
\left(\mu_{4}\right)\end{array}$ & $\operatorname{Very}$ high $\left(\mu_{5}\right)$ \\
\hline$a_{1}$ & 0.33 & 0 & 0 & 0 & 1 & 0 \\
\hline $\mathrm{a}_{2}$ & 0.33 & 0 & 0 & 0 & 0 & 1 \\
\hline$a_{3}$ & 0.33 & 0 & 0 & 0 & 0 & 1 \\
\hline \multicolumn{2}{|c|}{ Weight Levels } & 0.1 & 0.3 & 0.5 & 0.7 & 0.9 \\
\hline
\end{tabular}

Table 2: Matrix for Evaluation of the Integral Factor $B$

\begin{tabular}{|l|c|c|c|c|c|c|}
\hline \multirow{2}{*}{ Factors } & \multirow{2}{*}{ Weight } & \multicolumn{5}{|c|}{ Membership functions for levels of the constituent } \\
factors:
\end{tabular}

Integral factor A exploration work on the second object is defined by three basic factors with the system of weights and quantitative levels established by table 3, and the integral factor B of the same exploration identified eight basic factors with the system of weights and quantitative levels established by table 4 . Required to qualitatively determine the levels of integral factors A and B on the basis of three-level 01-classification. 
Table 3: Matrix for Evaluation of the Integral Factor $B$

\begin{tabular}{|l|c|c|c|c|c|c|}
\hline \multirow{2}{*}{ Factors } & \multirow{2}{*}{ Weight } & \multicolumn{5}{|c|}{ Membership Functions for Levels of the Constituent Factors: } \\
\cline { 3 - 7 } & Very Low $\left(\mu_{\mathbf{1}}\right)$ & $\begin{array}{l}\text { Low } \\
\left(\mu_{2}\right)\end{array}$ & $\begin{array}{l}\text { Average } \\
\left(\mu_{3}\right)\end{array}$ & $\begin{array}{l}\text { High } \\
\left(\mu_{4}\right)\end{array}$ & Very high $\left(\mu_{5}\right)$ \\
\hline $\mathrm{a}_{1}$ & 0.33 & 0 & 0 & 0 & 1 & 0 \\
\hline $\mathrm{a}_{2}$ & 0.33 & 0 & 0 & 0 & 0 & 1 \\
\hline $\mathrm{a}_{3}$ & 0.33 & 0 & 0 & 0 & 0 & 1 \\
\hline \multicolumn{2}{|r}{ Level Weights } & $\mathbf{0 . 1}$ & $\mathbf{0 . 3}$ & $\mathbf{0 . 5}$ & $\mathbf{0 . 7}$ & $\mathbf{0 . 9}$ \\
\hline
\end{tabular}

Table 4: Matrix for Evaluation of the Integral Factor $B$

\begin{tabular}{|l|l|c|c|c|c|c|}
\hline \multirow{2}{*}{ Factors } & \multirow{2}{*}{ Weight } & \multicolumn{5}{|c|}{ Membership Functions for Levels of the Constituent Factors: } \\
\cline { 3 - 7 } & & Very Low $(\mu \mathbf{1})$ & $\begin{array}{c}\text { Low } \\
(\boldsymbol{\mu} 2)\end{array}$ & $\begin{array}{c}\text { Average } \\
(\boldsymbol{\mu 3})\end{array}$ & $\begin{array}{c}\text { High } \\
(\boldsymbol{\mu 4})\end{array}$ & Very High $(\boldsymbol{\mu} \mathbf{5})$ \\
\hline b1 & 0.125 & 0 & 0 & 0 & 1 & 0 \\
\hline b2 & 0.125 & 0 & 0 & 1 & 0 & 0 \\
\hline b3 & 0.125 & 0 & 0 & 0 & 1 & 0 \\
\hline b4 & 0.125 & 0 & 0 & 0 & 1 & 0 \\
\hline b5 & 0.125 & 0 & 0 & 0 & 0 & 1 \\
\hline b6 & 0.125 & 0 & 0 & 0 & 0 & 1 \\
\hline b7 & 0.125 & 0 & 0 & 0 & 1 & 0 \\
\hline b8 & 0.125 & 0 & 0 & 0 & 1 & 0 \\
\hline \multicolumn{2}{|c|}{ Level Weights } & $\mathbf{0 . 1}$ & $\mathbf{0 . 3}$ & $\mathbf{0 . 5}$ & $\mathbf{0 . 7}$ & $\mathbf{0 . 9}$ \\
\hline
\end{tabular}

In recognition, we took as a basis the set of membership functions in the form of Figure 3 . The membership function of a subset "High level of a factor" that is defined on 01-carrier $\mathrm{x}$ has the following analytical form:

$$
\mu_{3}(x)=\left\{\begin{array}{c}
0,0 \leq x<0.6 \\
5(x-0.6), 0.6 \leq x<0.8 \\
1,0.8 \leq x \leq 1
\end{array}\right.
$$

In turn, the membership function of a subset "Average level of a factor" has the following analytical form:

$$
\mu_{2}(x)=\left\{\begin{array}{c}
0,0 \leq x<0.2 \\
5(x-0.2), 0.2 \leq x<0.4 \\
1,0.4 \leq x<0.6 \\
5(0.8-x), 0.6 \leq x<0.8 \\
0,0.8 \leq x<=1
\end{array}\right.
$$

Respectively is performed:

$\mu_{1}(\mathrm{x})=1-\mu_{2}(\mathrm{x})-\mu_{3}(\mathrm{x})$.

Calculation for (1) with reference to tables 1 and 2 gives:

$\mathrm{A}=0,891$,

$B=65$,

that the recognition by the formulas (4), (5) positions:

level And $100 \%$ as high ; 
level B 25\% as average and $75 \%$ as average. Calculation for (1) with reference to tables 3 and 4 gives:

$$
\begin{aligned}
& A=0,891, \\
& B=725,
\end{aligned}
$$

that the recognition by the formulas (4), (5) positions:

- Level A $100 \%$ as high ;

- Level B by $63 \%$ as average and $37 \%$ as average.

Now, recognizing the levels of $\mathrm{A}$ and $\mathrm{B}$, it is possible to position the exploration. In table 5 summarized the position of the model $[3,4]$ and a possible strategy of conducting exploration works.

\begin{tabular}{|c|c|c|c|c|}
\hline \multirow[t]{2}{*}{ No } & \multicolumn{2}{|c|}{$\begin{array}{l}\text { Levels of } \\
\text { Factors } \\
\text { According to } \\
\text { Indicators }\end{array}$} & \multirow[t]{2}{*}{ Position Name and Brief Description } & \multirow[t]{2}{*}{ Possible Business Strategies } \\
\hline & $\mathbf{A}$ & $\mathbf{H}$ & & \\
\hline 1 & $\mathrm{H}$ & $\mathrm{H}$ & $\begin{array}{l}\text { Leader } \\
\text { The industry is attractive and exploration have } \\
\text { it in a strong position as a leader; the potential } \\
\text { market is large, the market growth rate is high; } \\
\text { the weaknesses of exploration and explicit } \\
\text { threats by competitors is not marked. }\end{array}$ & $\begin{array}{l}\text { To continue investing in exploration, while } \\
\text { the industry continues to grow, in order to } \\
\text { protect their leading position; we will need } \\
\text { large investment (more than can be provided } \\
\text { at the expense of own assets); to continue to } \\
\text { invest at the expense of short-term profits for } \\
\text { future profits. }\end{array}$ \\
\hline 2 & $\mathrm{H}$ & A & $\begin{array}{l}\text { Growth strategy } \\
\text { Theindustry is moderately attractive, but } \\
\text { exploration occupies a strong position. Such } \\
\text { exploration is one of the leaders. The market } \\
\text { is moderately growing or stable with good } \\
\text { margin and without the presence on it of any } \\
\text { other strong competitor. }\end{array}$ & $\begin{array}{l}\text { To try to keep their positions; the position can } \\
\text { provide the necessary financial resources for } \\
\text { self or to give additional money to invest in } \\
\text { other promising areas of exploration. }\end{array}$ \\
\hline 3 & $\mathrm{H}$ & $\mathrm{H}$ & $\begin{array}{l}\text { Cash Generator Strategy } \\
\text { Geological exploration occupies a rather strong } \\
\text { position in an unattractive industry. It, if not } \\
\text { the leader, then one of the leaders here. The } \\
\text { market is stable, but declining, and the rate of } \\
\text { profit in the industry is declining. There is a } \\
\text { certain threat from competitors, although } \\
\text { productivity is high, and costs are low. }\end{array}$ & $\begin{array}{l}\text { Exploration work falling into this cell is the } \\
\text { main source of income. Since no further } \\
\text { development of geological exploration data is } \\
\text { required in the future, the strategy is to make } \\
\text { insignificant investments, extracting the } \\
\text { maximum revenue. }\end{array}$ \\
\hline 4 & A & $\mathrm{H}$ & $\begin{array}{l}\text { Strategy for enhancing competitive } \\
\text { advantages } \\
\text { Exploration takes an intermediate position in } \\
\text { an attractive industry. As market share, } \\
\text { product quality, and reputation is quite high } \\
\text { (almost the same as the branch leader), } \\
\text { exploration can become a leader if they put } \\
\text { their resources properly. Before you bear any } \\
\text { of the costs, in this case, it is necessary to } \\
\text { carefully analyze the dependence of the } \\
\text { economic effects of investment, in the } \\
\text { industry. }\end{array}$ & $\begin{array}{l}\text { Invest if exploration is worth it while making } \\
\text { the necessary detailed analysis of investments; } \\
\text { to move into the position of a leader, a large } \\
\text { investment will be required; Geological } \\
\text { exploration is considered as very suitable for } \\
\text { investment, if it can provide increased } \\
\text { competitive advantages. The necessary } \\
\text { investments will be greater than the expected } \\
\text { income, and therefore additional capital } \\
\text { investments may be required to continue to } \\
\text { struggle for their market share. }\end{array}$ \\
\hline
\end{tabular}

Table 5: Positions of Geological Prospecting Works 


\begin{tabular}{|c|c|c|c|c|}
\hline \multicolumn{5}{|c|}{ Table 5: Contd., } \\
\hline 5 & A & A & $\begin{array}{l}\text { Continue geological exploration with } \\
\text { caution } \\
\text { Geological exploration occupies middle } \\
\text { positions in the industry with average } \\
\text { attractiveness. There are no special strengths or } \\
\text { opportunities for further development in } \\
\text { geological exploration; the market is growing } \\
\text { slowly; the industry average rate of profit is } \\
\text { slowly decreasing. }\end{array}$ & $\begin{array}{l}\text { Invest cautiously and in small portions, being } \\
\text { sure that the return will be fast and constantly } \\
\text { conduct a thorough analysis of your economic } \\
\text { situation. }\end{array}$ \\
\hline 6 & A & $\mathrm{H}$ & $\begin{array}{l}\text { Strategy of partial coagulation } \\
\text { Geological exploration occupies middle } \\
\text { positions in an unattractive industry. There are } \\
\text { no particularly strong sides and virtually no } \\
\text { opportunities for development in geological } \\
\text { exploration; the market is unattractive (low- } \\
\text { profit margins, potential surplus production } \\
\text { capacity, high capital density in the industry). }\end{array}$ & $\begin{array}{l}\text { Since it is unlikely that geological exploration } \\
\text { will continue to earn a significant income by } \\
\text { getting into this position, it is not the } \\
\text { proposed strategy to develop this type of } \\
\text { work, but to try to turn physical assets and } \\
\text { position on the market into a money supply, } \\
\text { and then use its own resources to develop } \\
\text { more promising work. }\end{array}$ \\
\hline 7 & $\mathrm{H}$ & $\mathrm{H}$ & $\begin{array}{l}\text { To double the volume of production or to } \\
\text { curtail geological exploration work } \\
\text { Geological exploration occupies weak } \\
\text { positions in an attractive industry. }\end{array}$ & $\begin{array}{l}\text { Invest or leave this work. As an attempt to } \\
\text { improve the competitive position of such } \\
\text { exploration through a broad-front attack } \\
\text { would require very large and risky } \\
\text { investments, it can only be undertaken after a } \\
\text { detailed analysis. If it is established that the } \\
\text { organization that carried out geological } \\
\text { exploration works can compete for the leading } \\
\text { positions in the industry, then the strategic } \\
\text { line is "doubling". Otherwise, a strategic } \\
\text { decision should be to leave this job. }\end{array}$ \\
\hline 8 & $\mathrm{H}$ & A & $\begin{array}{l}\text { Continue geological exploration with } \\
\text { caution or partially curtail the production } \\
\text { off } \\
\text { Geological exploration occupies weak } \\
\text { positions in moderately attractive industry. }\end{array}$ & $\begin{array}{l}\text { No investments; all management should be } \\
\text { focused on the balance of cash flow; try to } \\
\text { keep in this position until it makes a profit; } \\
\text { gradually curtail the work. }\end{array}$ \\
\hline 9 & $\mathrm{H}$ & $\mathrm{H}$ & $\begin{array}{l}\text { Closing strategy for geological exploration } \\
\text { Geological exploration occupies weak } \\
\text { positions in an unattractive industry. }\end{array}$ & $\begin{array}{l}\text { As the organization that falls into this cell as a } \\
\text { whole is losing money, you need to make } \\
\text { every effort to get rid of such work, and the } \\
\text { sooner the better. }\end{array}$ \\
\hline
\end{tabular}

\section{CONCLUSIONS}

We see that the conditions of calculation example of the estimated exploration are positioned at row 5 of table 4 to "Continue exploration with caution." While some displacement in the area of high competitiveness (A+) suggests that exploration has growing competitive advantages that, in the presence of precautionary investment may allow it to occupy a larger market share of sales, i.e. to increase the mass of profit.

\section{REFERENCES}

1. K. SUDHAKAR, S. NAGANJANEYULU \& Y. RAMA MOHAN. A SURVEY ON COMPUTER AUTOMATED TRADING IN INDIAN STOCK MARKETS.// International Journal of Mechanical and Production Engineering Research and Development (IJMPERD).ISSN(P): 2249-6890; ISSN(E): 2249-8001 Vol. 8, Issue 1, Feb 2018, 531-540 
2. Chaboud et al., "Rise of the Machines: Algorithmic Trading in the Foreign Exchange Market," Int'l Finance Discussion

Papers, Board of Governors of the Federal Reserve System, Oct. 2009; www.federalreserve.gov/pubs/ifdp/2009/980/ifdp980.pdf.

3. VENNILA SHREE S, PUGAZHENTHI R, FRANKLIN ISSAC R3 \& PARTHIBAN. A. CONCEPT OF LOGICAL SORT FOR IDLE TIME MINIMIZATION OF RENTAL/CRITICAL MACHINE IN FLOWSHOP //International Journal of Mechanical and ProductionEngineering Research and Development (IJMPERD)ISSN (P): 2249-6890; ISSN (E): 2249-8001Vol. 8, Issue 1, Feb 2018, 589-594.

4. RAJAN \& VINEET KUMAR. A RESTART SCHEME BASED META HEURISTIC FOR FLEXIBLE JOB SHOP SCHEDULING // International Journal of Mechanical and Production Engineering Research and Development (IJMPERD) ISSN(P): 22496890; ISSN(E): 2249-8001 Vol. 8, Issue 1 Feb 2018, 681-690.

5. BALASUBRAMANIAN. A NEW MODEL FOR CONSISTENCY CENTERED MAINTENANCE IN PETROLEUM REFINERY // International Journal of Mechanical and Production Engineering Research and Development (IJMPERD).ISSN (P): 2249 6890; ISSN (E): 2249-8001Vol. 8, Issue 1, Feb 2018, 791-798. 